\title{
Simulated melt rates for the Totten and Dalton ice shelves
}

\author{
D. E. Gwyther ${ }^{1,2}$, B. K. Galton-Fenzi ${ }^{3,2}$, J. R. Hunter ${ }^{2}$, and J. L. Roberts ${ }^{3,2}$ \\ ${ }^{1}$ Institute for Marine and Antarctic Studies, University of Tasmania, Private Bag 129, Hobart, Tasmania 7001, Australia \\ ${ }^{2}$ Antarctic Climate \& Ecosystems Cooperative Research Centre, University of Tasmania, Private Bag 80, Hobart, \\ Tasmania 7001, Australia \\ ${ }^{3}$ Australian Antarctic Division, Channel Highway, Kingston, Tasmania 7050, Australia \\ Correspondence to: D. E. Gwyther (david.gwyther@gmail.com)
}

Received: 9 October 2013 - Published in Ocean Sci. Discuss.: 13 November 2013

Revised: 18 March 2014 - Accepted: 20 March 2014 - Published: 6 May 2014

\begin{abstract}
The Totten Glacier is rapidly losing mass. It has been suggested that this mass loss is driven by changes in oceanic forcing; however, the details of the ice-ocean interaction are unknown. Here we present results from an ice shelf-ocean model of the region that includes the Totten, Dalton and Moscow University ice shelves, based on the Regional Oceanic Modeling System for the period 1992-2007. Simulated area-averaged basal melt rates (net basal mass

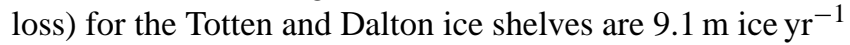

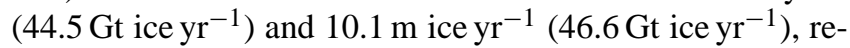
spectively. The melting of the ice shelves varies strongly on seasonal and interannual timescales. Basal melting (mass loss) from the Totten ice shelf spans a range of $5.7 \mathrm{~m}^{\text {ice }} \mathrm{yr}^{-1}$ $\left(28 \mathrm{Gt}^{\text {ice } \mathrm{yr}^{-1}}\right.$ ) on interannual timescales and $3.4 \mathrm{~m}^{-1} \mathrm{yr}^{-1}$ $\left(17 \mathrm{Gt}^{\mathrm{t}}\right.$ ice $\left.\mathrm{yr}^{-1}\right)$ on seasonal timescales.

This study links basal melt of the Totten and Dalton ice shelves to warm water intrusions across the continental shelf break and atmosphere-ocean heat exchange. Totten ice shelf melting is high when the nearby Dalton polynya interannual strength is below average, and vice versa. Melting of the Dalton ice shelf is primarily controlled by the strength of warm water intrusions across the Dalton rise and into the ice shelf cavity. During periods of strong westward coastal current flow, Dalton melt water flows directly under the Totten ice shelf further reducing melting. This is the first such modelling study of this region to provide a valuable framework for directing future observational and modelling efforts.
\end{abstract}

\section{Introduction}

Understanding how changing ocean circulation and properties are causing increased basal melt of Antarctic ice shelves is crucial for predicting future sea level rise. The Totten Glacier (see Fig. 1) drains over $570000 \mathrm{~km}^{2}$ of East Antarctica (Rignot et al., 2008). Most of the ice sheet that drains through the Totten Glacier is from the Aurora Subglacial Basin (Young et al., 2011) and is marine based (i.e. the ice base is grounded below sea level; Roberts et al., 2011) making the region potentially vulnerable to rapid ice sheet collapse. Weertman (1974) showed that ice grounded below sea level is inherently unstable, particularly where the bedrock slopes downwards, away from the ocean, as is the case in the Aurora Subglacial Basin (Young et al., 2011). More recent studies have indicated lateral stresses may act to stabilise ice retreat on a reverse bed slope (Jamieson et al., 2012), but the applicability of this on a broad drainage basin, where lateral stresses are lower, is uncertain.

The Antarctic ice sheet contains enough ice to raise sea level by over 58 metres (Fretwell et al., 2013). Observations of global mean sea level rise over the period 1993-2008, indicate an average rate of $2.61 \pm 0.55 \mathrm{~mm} \mathrm{yr}^{-1}$, with an Antarctic contribution of $0.43 \pm 0.2 \mathrm{~mm} \mathrm{yr}^{-1}$ (Church et al., 2011). Projections of sea level rise have a large uncertainty in the contribution of Antarctica, due to lack of observations of ice discharge rates and surface mass balance (Gregory et al., 2013).

The ice sheet flows towards the ocean through both broad, slow ice-sheet flow and many fast-flowing glaciers. Ice shelves form in coastal regions where the ice thickness of the ice sheet or glacier is insufficient to maintain contact 


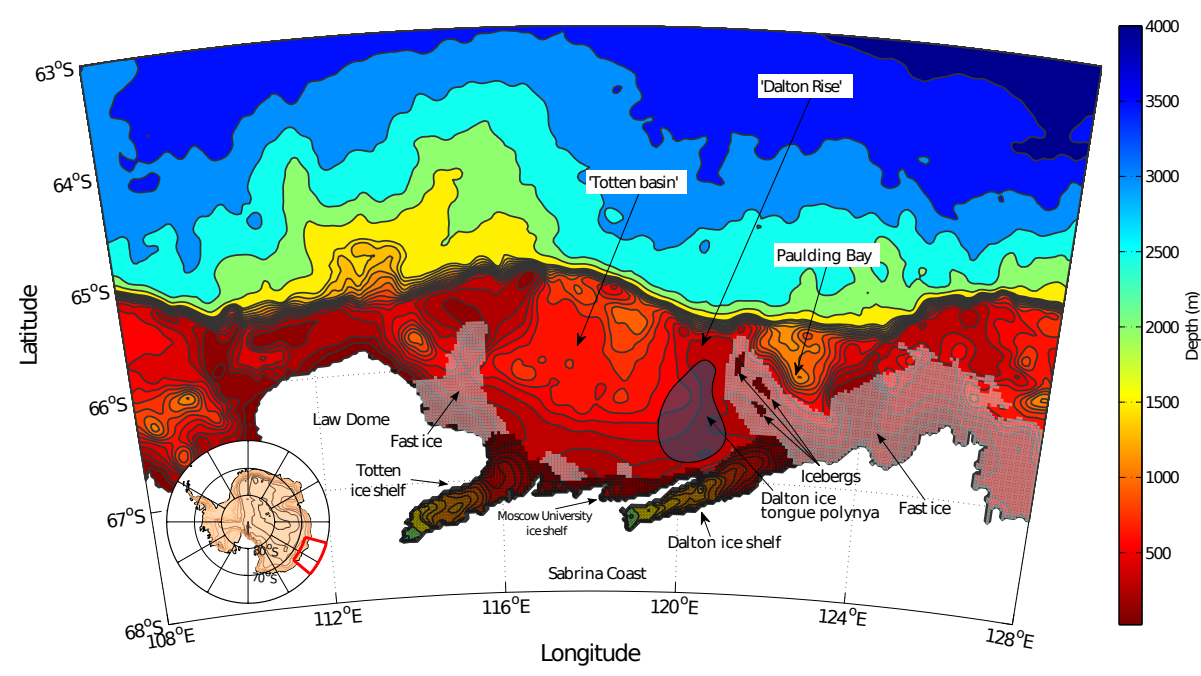

Fig. 1. Model bathymetry and domain. The contour interval is $100 \mathrm{~m}$ up to $1500 \mathrm{~m}$ depth and $500 \mathrm{~m}$ up to $4000 \mathrm{~m}$ depth. Ice shelves and icebergs (dark shading), fast ice (bright shading), polynya (mauve shading with dark outline) and major bathymetric features are indicated. Inset shows model domain location in Antarctica.

with the bedrock and the ice begins to float on the ocean. An ocean-filled cavity, insulated from the atmosphere, forms beneath. The sub-ice shelf seabed can be found at depths of over $2800 \mathrm{~m}$ below mean sea level (e.g. the deepest part of the Amery ice shelf cavity; Galton-Fenzi et al., 2008). The freezing point of seawater decreases with increasing pressure. Therefore, at the back of deep ice-shelf cavities, the decreased freezing point of seawater provides a large potential for thermal driving of melting, leading to melting at depth and a buoyant melt water plume (Lewis and Perkin, 1986).

Increased melting leads to the localised thinning of an ice shelf, and potentially to the acceleration of the glacier behind it, as the buttressing effect of the shelf is decreased (Dupont and Alley, 2005). An acceleration in flow rate of a glacier causes a mass budget imbalance in the surrounding ice sheet due to the longer response time of the interior ice sheet to flow change; hence the grounded ice sheet thins. For example, observations show surging, acceleration and retreat of tributary glaciers after the collapse of the Larsen A and B ice shelves (De Angelis and Skvarca, 2003; Scambos et al., 2004). It is this dynamic coupling between the ice shelf and the glacier which makes the grounded ice sheet susceptible to oceanic changes (Dupont and Alley, 2005). The ice shelfocean interaction is therefore an important control on the discharge of grounded ice into the oceans and subsequently on sea level. Recent satellite observations have shown rapid and accelerated thinning of glaciers along the coastal margins of Antarctica (Pritchard et al., 2009). For example, Pine Island Glacier thinned at rates up to $6 \mathrm{~m} \mathrm{yr}^{-1}$ while the Totten Glacier displayed thinning rates of $1.9 \mathrm{~m} \mathrm{yr}^{-1}$ for the period 2003-2007 (Pritchard et al., 2009), three times the rate previously reported (Rignot, 2006). The high thinning rates of marine terminating glaciers suggests a common oceanic driving, for example through increased basal melting (Pritchard et al., 2012).

Glaciologically derived estimates of area-averaged basal melt rate for the Totten ice shelf are $20 \pm 9 \mathrm{~m} \mathrm{yr}^{-1}$ (Rignot, 2002); $26 \pm 8 \mathrm{~m} \mathrm{yr}^{-1}$ (Rignot and Jacobs, 2002); and $10.5 \pm$ $0.7 \mathrm{~m} \mathrm{yr}^{-1}$ (Rignot et al., 2013). These estimates are derived from satellite interferometric synthetic aperture radar (InSAR) observations of ice surface velocity and the first two are calculated as the difference in flux of ice from the Totten Glacier across the grounding line and across a flux gate 10-30 km downstream, divided by the area of enclosed ice shelf. These measurements should thus be treated as an average melt rate for the grounding line region. The latter estimate was also derived from InSAR observations, but was calculated using the volume flux divergence for the whole ice shelf area. The last estimate is equivalent to a mass loss rate of $63.2 \pm 4 \mathrm{Gt} \mathrm{yr}^{-1}$ (Rignot et al., 2013). Comparatively, the InSAR estimate for the Moscow University Ice Shelf shows basal melt of $4.7 \pm 0.8 \mathrm{~m} \mathrm{yr}^{-1}$ and a mass loss rate of $27.4 \pm 4 \mathrm{Gt} \mathrm{yr}^{-1}$ (Rignot et al., 2013). It should be noted that this work defines the Dalton ice shelf as being separate from the Moscow University Ice Shelf. We define the Dalton ice shelf as the ice shelf separated from the ocean by the grounded peninsula which runs north-east from $67.2^{\circ} \mathrm{S}$, $118.5^{\circ} \mathrm{E}$. This is done since the grounded peninsula is likely to protect the Dalton ice shelf from oceanic influences, and will change the mass loss characteristics of the Dalton as compared to the Moscow University Ice Shelf.

These estimates show the Totten and Dalton basal melting and mass loss to be exceptionally high compared to other ice shelves in East Antarctica (Rignot et al., 2013). Other East Antarctic ice shelves that are experiencing similar basal melt rates are typically smaller ice shelves, and thus mass loss 
rates are smaller than the mass loss of the Totten. For example, the Wilma/Robert/Downer ice shelves have a basal melt rate of $11.7 \pm 0.7 \mathrm{~m} \mathrm{yr}^{-1}$, but with an area of only $858 \mathrm{~km}^{2}$, mass loss $\left(10.0 \pm 0.6 \mathrm{Gt} \mathrm{yr}^{-1}\right)$ is only $16 \%$ as large as the Totten mass loss. Furthermore, unlike many other high melt locations, such as the Pine Island ice shelf which is estimated to have an area-averaged mass loss of $101.2 \pm 8 \mathrm{Gt} \mathrm{yr}^{-1}$ (Rignot et al., 2013), no definite causal mechanisms for basal melting of the Totten and Dalton ice shelves are known.

Here we examine the temporal variability and driving mechanisms controlling the basal melt rates of the Totten and Dalton ice shelves using a numerical model. The Totten and Dalton ice shelves are prime candidates for investigation, due to their rapid thinning rates, high estimated basal melt and the limited existing research. Section 2 provides an overview of the Totten and Dalton ice shelf-ocean region. Section 3 presents different hypotheses for drivers of basal melting and in Sect. 4, the regional circulation and heat transport model is described. Sections 5 and 6 present the results of the modelling and a discussion on cross shelf flow and atmosphere exchange processes.

\section{Description of region}

The Totten ice shelf (centred at $67^{\circ} \mathrm{S}, 116^{\circ} \mathrm{E}$ ) is located on the Sabrina coast in East Antarctica (see Fig. 1). The Sabrina coast is characterised by marine terminating glaciers, ice shelves (such as the Totten, Moscow University and Dalton ice shelves), large tracts of year-round ice adjoining the land (fast ice), extensive seasonal sea ice growth and a region of strong sea ice formation (the Dalton ice tongue polynya). The continental shelf seas are approximately $1000 \mathrm{~m}$ deep, with the shelf break occurring between $65^{\circ} \mathrm{S}$ to $65.5^{\circ} \mathrm{S}$ in this region. The Antarctic Circumpolar Current is located in the deep abyssal waters to the north of the continental shelf break (Orsi et al., 1995). The Antarctic Circumpolar Current is composed of several water masses, with the Antarctic Surface Water overlying relatively warm and salty Circumpolar Deep Water (CDW). Poleward mixing of CDW with cold and dense Antarctic waters produces "modified" CDW or MCDW (Orsi et al., 1995), at the southern boundary of the Antarctic Circumpolar Current.

The embayed position of the Totten ice shelf, located on the eastern flank of Law Dome and with a broad continental shelf, makes it relatively isolated from the eastward flowing Antarctic Circumpolar Current. The two main oceanic currents near to the coastal ice shelves flow westwards. The Antarctic Coastal Current (ACoC) flows within $50 \mathrm{~km}$ of the coast and is associated with the east wind drift. The Antarctic Slope Current (ASC) is topographically controlled and is an important influence on transport across the continental shelf break (Jacobs, 1991).

A large polynya forms west of the Dalton ice shelf tongue (Massom et al., 1998). Polynyas form when strong gravity-driven katabatic winds flow down the Antarctic ice sheet and turn westwards under Coriolis acceleration, removing freshly formed sea ice. Heat is then lost from the uncovered ocean, leading to more sea ice formation and brine rejection as a latent-heat polynya. These are important as they produce large quantities of high-salinity shelf water (HSSW), which contribute to bottom water formation (Rintoul et al., 2001), an important driver of the global climate system (Jacobs, 2004). The easterly katabatic winds are an important controlling factor in polynya strength (Massom et al., 1998). As the ACoC is also controlled by the strength of the easterly winds, a correlation between the strength of both the polynya and the $\mathrm{ACoC}$ is to be expected.

\section{Overview of drivers of basal melting}

The largest process responsible for causing ice shelf thinning is thought to be changes in the magnitude of basal melting (Pritchard et al., 2012; Rignot et al., 2013; Depoorter et al., 2013). Ice shelf thinning by increased basal melt suggests increased oceanic heat available for melting at the ice shelf cavity (Holland et al., 2008; Jacobs et al., 2013). Proposed hypotheses explaining increased heat supply to ice shelf cavities include; redirected coastal ocean currents leading to increased heat content beneath ice shelves (Hellmer et al., 2012; Jacobs et al., 2011); regional upper-ocean hydrography (Hattermann et al., 2014); dynamic eddy-scale activity (Moffat et al., 2009); a link with sea ice conditions (Holland et al., 2010); polynya activity (Cougnon et al., 2013); winddriven currents (Dinniman and Klinck, 2004); and changes in the Antarctic Circumpolar Current (Gille, 2008; Böning et al., 2008). This paper investigates the mechanisms that influence the oceanic heat supply that drives basal melting.

\subsection{Circumpolar Deep Water intrusions}

Increased heat supply for ice shelf melting has been suggested to be due to periodic incursions of modified Circumpolar Deep Water (MCDW) onto the continental shelf which can then flow along isopycnals and be delivered to the ice shelf base (Jacobs et al., 1996; Thoma et al., 2008). Observations near and beneath several Antarctic ice shelves show the signature of MCDW. In the case of Pine Island ice shelf, which is showing high melt rates, water measurements taken from an autonomous underwater vehicle show MCDW mixing with cold melt water. This indicates that MCDW is responsible for the high melt rates of Pine Island ice shelf (Jenkins et al., 2010; Jacobs et al., 2011).

In the Totten Glacier region, Conductivity, Temperature and Depth (CTD) measurements have indicated the presence of MCDW on the south side of the continental shelf break, $\sim 200 \mathrm{~km}$ from the Totten ice shelf (Williams et al., 2011). However, no observations yet exist to determine the temporal and spatial variability or causal mechanism of the MCDW 
incursion. Consequently, it is not yet clear whether MCDW is the water source driving melting of the Totten ice shelf.

\subsection{Interaction with bathymetric features}

Observations suggest that intrusions of warm water onto the continental shelf are highly dependent on bathymetric features (e.g. Martinson and McKee, 2012). Geostrophic eddy interaction with small scale bathymetry features can lead to enhanced oceanic mixing via internal wave breaking (Nikurashin and Ferrari, 2010). Broad scale bathymetry features such as the shelf break (as opposed to small scale sills and ridges) can also lead to net onshore intrusion. Inertia of the along-slope water flow can carry the water up the slope and onto the shelf, depending on the curvature and orientation of the continental shelf (Dinniman and Klinck, 2004; Klinck and Dinniman, 2010). In the case of Pine Island Glacier, modelling has shown warm waters being channelled through irregular bathymetric features and submarine troughs (Thoma et al., 2008). The bathymetry in front of the Totten ice shelf is suggestive of possible pathways of MCDW intrusion onto the continental shelf. For example, Paulding Bay (see Fig. 1) is bordered by a low continental shelf break, possibly allowing bathymetric intrusion. The western side of the Dalton rise is another location where the deepening of the continental shelf break may allow intrusion of MCDW. Current bathymetry products of the continental shelf break and shelf proper in this region are informed by satellite gravity inversions, and have limited ship-based groundtruthing. Consequently, there is a strong need to acquire accurate shipbased and airborne bathymetry data.

\subsection{Eddies}

Eddies may also transport and mix heat across the shelf break. Observations in the western Antarctic Peninsula have characterised eddies as transporting Circumpolar Deep Water onto the continental shelf (see Moffat et al., 2009). The Antarctic Circumpolar Current is recognised as an important generator of eddies, which carry heat polewards (Rintoul et al., 2001). Closer to the continental shelf, interaction of the westward flowing coastal current with bathymetric features, such as ridges along the shelf break may lead to eddy generation. Numerical models have shown topographic Rossby wave interaction with bathymetry is an important factor for generating eddies, which carry a significant amount of heat across the continental shelf (St-Laurent et al., 2013).

Direct modelling of eddy generation and evolution is limited by model grid resolution and bathymetry detail. Eddypermitting flow can be simulated with horizontal grid resolutions of approximately 2-3 km (Klinck and Dinniman, 2010), however, a horizontal grid resolution of $1 \mathrm{~km}$ is required in order to resolve individual eddies (St-Laurent et al., 2013). The modelling work presented here (with a horizontal grid resolution of 2.5-3.5 km) is eddy-permitting, where the mean flow and associated interactions are resolved.

\subsection{Atmospheric forcing}

In analysing the source of increased heat supply to the Totten ice shelf region, we must also consider the effect of the atmospheric forcing on the ocean. Atmospheric forcing consists of transfers of momentum (surface wind stress) and buoyancy (heat and/or salt fluxes), such brine rejection in sea ice formation and polynya regions.

In some cases, local meteorological conditions favour wind stress patterns that drive currents over the continental shelf break and onto the shelf. For example, modelling of Pine Island ice shelf showed a strong correlation between flow of CDW onto the continental shelf and local temporal variations in synoptic wind stress conditions (Thoma et al., 2008).

The polynya located to the east of the Totten ice shelf produces dense HSSW. HSSW flow may interact in different ways with the local environment, and until observations are taken, modelling presents the only method to understand the implications of the polynya for the oceanography of the region. Kämpf (2005) suggested that dense water cascading down submarine canyons and off the shelf break could induce upwelling of deeper water onto the shelf, which was confirmed in numerical simulations and laboratory experiments (Kämpf, 2007). Alternatively, HSSW produced by polynya activity could be guided by the westward flowing coastal current, directly towards the mouth of the Totten ice shelf cavity, potentially cooling sub-ice shelf waters and quenching melting.

Ice concentration observations taken by the Special Sensor Microwave Imager are used to infer heat and salt flux out of the ocean (Tamura et al., 2008). The heat flux out of the Dalton ice tongue polynya using the method of Tamura et al. (2008) is shown in Fig. 2a, where a positive value indicates loss of heat to the atmosphere and formation of HSSW, and is considered as a proxy for polynya activity. A peak in polynya activity coincides with the Austral winter, due to strong wind over the region (see Fig. 2a, green line) and low air temperatures. Between approximately mid-February and mid-November the polynya removes heat from the ocean. The persistence and duration of this polynya before the satellite era is unknown.

Long-term polynya activity can be analysed by considering the polynya heat flux anomaly - calculated as the difference between the heat flux and a climatological value for each month, smoothed with a Gaussian filter (the filter standard deviation is $\sigma_{\text {filter }}=4$ ), as shown in Fig. $2 \mathrm{~b}$. The climatology is calculated over the 1992-2007 period. The heat flux anomaly for the Dalton ice tongue polynya region is derived from the buoyancy flux data (see Tamura et al., 2008) used to force the open ocean surface of the model. A positive heat flux anomaly indicates above average heat loss from 


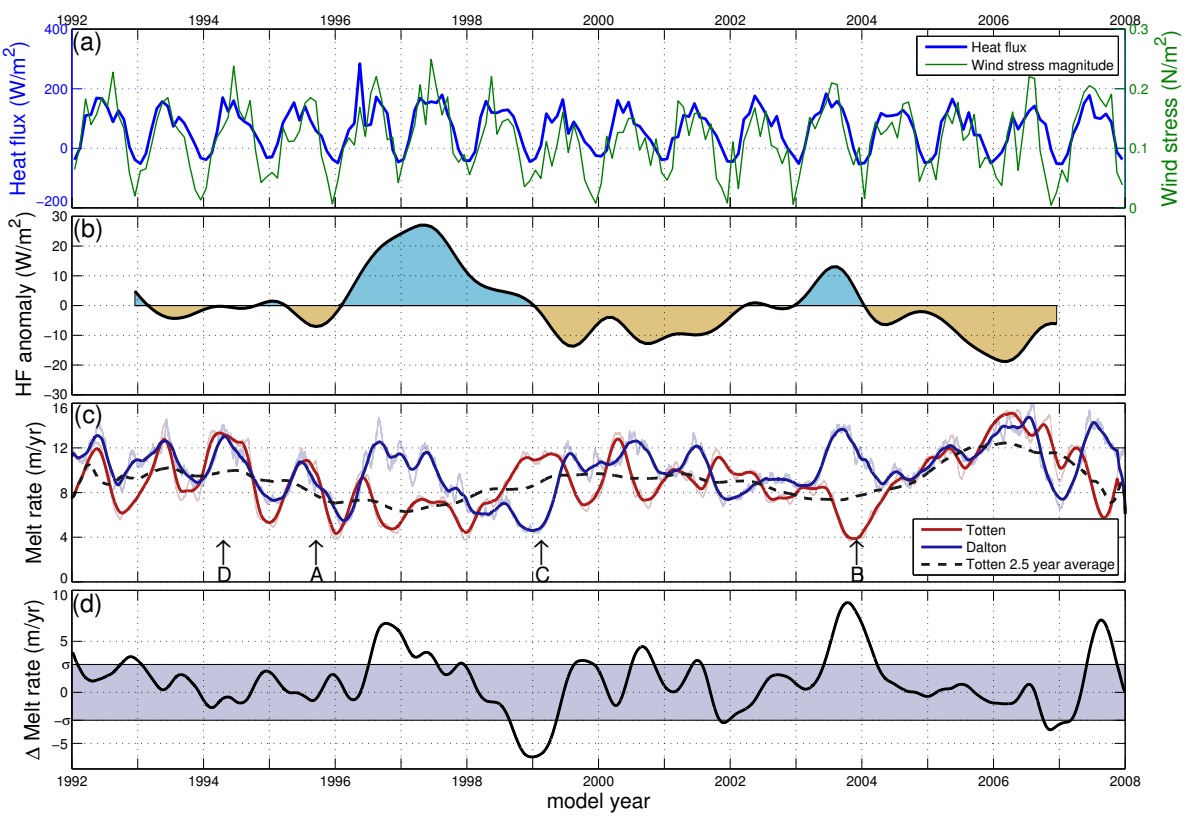

Fig. 2. (a) Heat flux out of ocean from SSM/I observations (Tamura et al., 2008) and the magnitude of wind stress, for the Dalton ice tongue polynya. (b) Difference between monthly heat flux and climatological heat flux (calculated from 1992-2007 data) for respective months, smoothed with a Gaussian filter $\left(\sigma_{\text {filter }}=4\right)$, and referred to as the "heat flux anomaly". Heat flux is defined out of the ocean, so positive anomaly periods indicate stronger than average heat loss from the ocean. (c) Model melt rates for the Totten and Dalton ice shelves. The times of the snapshots in Fig. 5 are marked A to D. (d) Difference between melt rates of the Totten and Dalton ice shelves. A positive difference indicates Dalton melting that is stronger than Totten melting. Raw melt rates are smoothed with a 2.5 -year moving average filter, \pm 1 standard deviation $\left(2.3 \mathrm{~m} \mathrm{yr}^{-1}\right)$ of difference is shaded and years are marked for the 1st of January. In (c), light blue and light red lines are the raw Dalton and Totten melt rates, blue and red lines are the raw melt rates smoothed with a 3-month moving average filter and the dashed black line is the Totten melt rate smoothed with a 2.5 -year moving average filter.

the ocean and stronger than average polynya activity and thus, the resulting signal is a proxy for interannual polynya strength.

\section{Model details}

A modified version of Regional Oceanic Modeling System (ROMS; Shchepetkin and McWilliams, 2005), a 3-D primitive equation finite difference model, is used to simulate ice shelf-ocean interaction. ROMS was modified to include realistic tidal forcing, thermodynamic interaction between ocean and the ice shelf (see Galton-Fenzi et al., 2012; Dinniman et al., 2007) and frazil thermodynamics (see Galton-Fenzi et al., 2012). A three-equation formulation parameterises ice-ocean thermodynamics, following Holland and Jenkins (1999).

The model domain (part of which is shown in Fig. 1) covers $104.5^{\circ} \mathrm{E}$ to $130^{\circ} \mathrm{E}$ and $60^{\circ} \mathrm{S}$ to $68^{\circ} \mathrm{S}$, with a grid resolution of $2.5 \mathrm{~km}$ to $3.5 \mathrm{~km}$ and 31 terrain-following layers in the vertical. Model bathymetry in the open ocean is provided by RTOPO-1 (Timmermann et al., 2010), which in turn is based on S-2004 (Marks and Smith, 2006), a combination of the gravity map of Smith and Sandwell (1997) and the ship-based echo soundings of the General Bathymetry Chart of the Oceans (GEBCO; British Oceanographic Data Centre, 2003). Ice shelf thickness over the Totten, Dalton and Moscow University ice shelves is inferred by hydrostatic inversion of ICESat ice surface elevation measurements. The bathymetry under the ice shelves is unknown, so cavity thickness, $T_{\mathrm{C}}$, is set to a nominal depth, $T_{\mathrm{C}}=300 \mathrm{~m}$, representative of the typical thickness of an ice shelf cavity along the cavity centreline (Galton-Fenzi et al., 2008), while along the grounding line, $T_{\mathrm{C}}=0$. Within the cavity, $T_{\mathrm{C}}$ is linearly interpolated between the cavity centreline and grounding line, except where the centreline approaches the grounding line. Here, $T_{\mathrm{C}}$ is not set, allowing a smooth interpolation from grounding line to centreline. The choice of $T_{\mathrm{C}}$ along the centreline is justifiable, as uncertainty in this depth should only affect the spatial distribution of melt/freeze regions (Holland et al., 2008) and not open ocean circulation and heat transport into the cavity. Furthermore, the agreement between modelled basal melt rates and glaciological estimates (see Sect. 5.1) attests to the scale of the ocean cavity being of the correct order. Fast ice is included from the maps of Fraser et al. (2012) with a $5 \mathrm{~m}$ draft (Massom et al., 2001).

There are several sea ice models available for integration into ROMS (Budgell, 2005). However, sea ice production from coupled sea ice models is sensitive to the representation 
of grounded icebergs (Kusahara et al., 2010), leading to the possibility of poor representation of polynyas forming in the lee of grounded icebergs (such as the Dalton ice tongue polynya). Consequently, we parameterise sea ice formation using the heat and salt ux algorithms of Tamura et al. (2008), which incorporate observed ice concentration for the period 1992-2007 from the Special Sensor Microwave Imager (SSM/I).

Currents, heat and salt fluxes on the lateral boundaries are relaxed to monthly values from the ECCO2 reanalysis product (Menemenlis et al., 2008). The surface is forced with wind stress from COREv2 (Large and Yeager, 2009) and the buoyancy fluxes of Tamura et al. (2008).

The model was run for by 32 years; comprised of 16 years of repeated 1992 forcing, followed by observed forcing for the period 1992-2007. After the 16-year spinup phase, the model was observed to have attained a pseudo-steady state as shown by the total ocean heat content for the spinup phase in Fig. 3.

\section{Results}

\subsection{Computed ice shelf melt rate}

Melting and freezing at the ice-ocean interface is calculated for the ice in the domain. Area-averaged melt rates for the Totten and Dalton ice shelves are shown in Fig. 2c, while the spatial melt rate distributions are shown in Fig. 4. These are at the same times as the corresponding circulation patterns in Fig. 5. In Fig. 2c, the smoothed interannual Totten melt rate is shown by a dashed black line, and is calculated by smoothing the area-averaged Totten melt rate with a 2.5 -year moving average filter. The area of the Totten and Dalton ice shelves, which are used for calculating the area-averaged melt rates and mass loss, are defined as $5402 \mathrm{~km}^{2}$ and $5113 \mathrm{~km}^{2}$, respectively.

For both the Totten and Dalton ice shelves, simulated whole ice shelf area-averaged melt rates range from $4 \mathrm{~m}$ ice $\mathrm{yr}^{-1}$ to $16 \mathrm{~m}$ ice $\mathrm{yr}^{-1}$. The Totten ice shelf areaaveraged melt rate (mass loss) averaged over the period 1992-2007 is modelled as $9.1{\mathrm{~m} \mathrm{ice} \mathrm{yr}^{-1}}^{-1}\left(44.5 \mathrm{Gt}_{\text {ice }} \mathrm{yr}^{-1}\right)$, which compares well to the most recent estimate of areaaveraged melt rate of $10.5 \pm 0.7 \mathrm{~m} \mathrm{yr}^{-1}$ (Rignot et al., 2013). The interannual variability in the Totten melt rate (shown as the dashed black line in Fig. 2c) has a mean range of

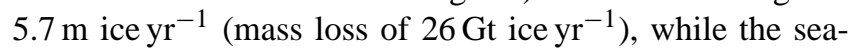
sonal variability has a mean range of $3.4 \mathrm{~m}^{\text {ice }} \mathrm{yr}^{-1}$ (mass loss of $17 \mathrm{Gt}$ ice $\mathrm{yr}^{-1}$ ). The area-averaged melt rate in the grounding line region is likely to be among the highest rates found under the Totten ice shelf. The model areaaveraged melt rate in the Totten grounding line region ranges

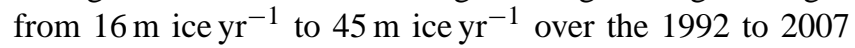

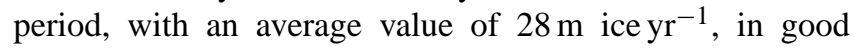

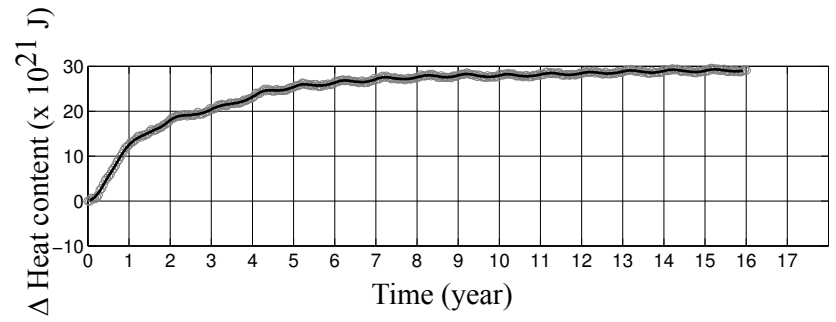

Fig. 3. The total ocean heat content within the model for the spinup period. In the spinup, the model is run with 1992 forcing repeated for 16 years.

agreement with the estimates from InSAR $\left(20 \pm 9 \mathrm{~m} \mathrm{yr}^{-1}\right.$; Rignot, 2002; $26 \pm 8 \mathrm{~m} \mathrm{yr}^{-1}$; Rignot and Jacobs, 2002).

While there are no glaciological estimates of melt rate for the Dalton ice shelf, the model area-averaged Dalton melt

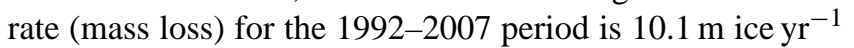
$\left(46.6 \mathrm{Gt}\right.$ ice $\left.\mathrm{yr}^{-1}\right)$. The strength of basal melt of the Dalton ice shelf, similar in magnitude to the Totten ice shelf, suggests that this region is also important for the Antarctic mass balance budget.

\subsection{Ocean circulation features}

Simulated model currents are shown in Fig. 5a-d. We find four different atmospheric and ocean circulation regimes, and subfigures in Fig. 5 are chosen at times representing these regimes. The model adequately reproduces the westward flowing $\mathrm{ACoC}$ with maximum transport during periods of strong easterly winds (see Fig. 5a), and very low transport during weak easterly winds (see Fig. 5d).

The ASC is also reproduced, flowing westwards along the continental shelf break (see Fig. 5b). The current is channelled by bathymetric features, such as where the shelf break curves north-west at $116^{\circ} \mathrm{E}, 64.5^{\circ} \mathrm{S}$ and approximately flows between the $2000 \mathrm{~m}$ and $2500 \mathrm{~m}$ isobaths. Consequently, the ASC is differentiated from coastal flow associated with the $\mathrm{ACoC}$ by both the zonal location and temperature of water within the flow. Currents for the ASC can be as high as $20 \mathrm{~cm} \mathrm{~s}^{-1}$, but have a mean flow of approximately $5 \mathrm{~cm} \mathrm{~s}^{-1}$. These model simulated currents agree well with the sparse nearby observations of Bindoff et al. (2000) and Williams et al. (2011), which reported observed currents of approximately $2-15 \mathrm{~cm} \mathrm{~s}^{-1}$ and $2.3-6.4 \mathrm{~cm} \mathrm{~s}^{-1}$, respectively. Modelling studies of circum-Antarctic ASC transport predict similar velocities (Mathiot et al., 2011).

The bathymetry of the continental shelf break acts to guide flow onto the shelf. The ASC interacts with several barriers as it flows westwards through the model domain. The eastern edge of the rise located at $122^{\circ} \mathrm{E}, 66^{\circ} \mathrm{S}$, henceforth named "Dalton rise" can act to guide water southwards towards the mouth of the Dalton ice shelf. West of the Dalton rise, a large basin with an average depth of $750 \mathrm{~m}$ exists, henceforth named the "Totten basin". Interaction of the westward 

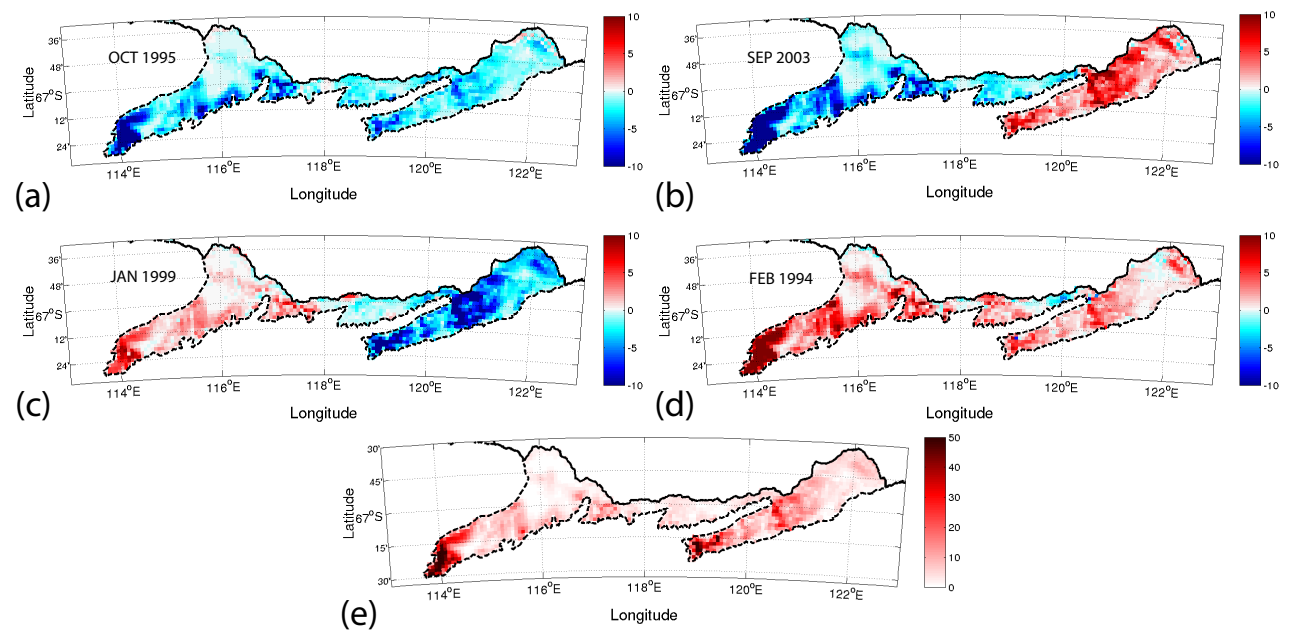

Fig. 4. The anomaly from the mean melt rate over the period 1992-2007 is shown at (a) October 1995 (b) September 2003 (c) January 1999 (d) February 1994. (e) The mean melt rate over the period 1992-2007. Larger positive numbers indicate higher melting.

flowing ASC with the the western edge of the Dalton rise generates a southward flowing jet clockwise around the Totten basin. This interaction, which is dependent on the meridional location of the ASC front, floods the Totten basin with warmer water, supplying heat that is available to drive the melting of the Totten ice shelf.

Observations to support these model results do not exist, as the region is covered by sea ice for much of the year. This makes long term estimation of sea surface currents by satellite observation impossible, and ship-borne observations sparse and difficult to acquire.

\subsection{Heat}

The temperature at each layer of the model generally decreases polewards. The water that makes up the ASC is typically between $0{ }^{\circ} \mathrm{C}$ to $0.4^{\circ} \mathrm{C}$, though at several points during the 1992-2007 time period, the temperature rises to approximately $0.5^{\circ} \mathrm{C}$. The water that makes up the $\mathrm{ACoC}\left(-1^{\circ} \mathrm{C}\right.$ to $-0.5^{\circ} \mathrm{C}$ ) is cooler than the ASC, as a result of mixing with cold meltwater from glaciers and ice shelves, and heat lost to the atmosphere.

Model output shows vertical water structure at the shelf break generally composed of relatively warm and salty CDW (with temperatures warmer than $1^{\circ} \mathrm{C}$ and salinity approximately 34.7) overlayed with fresher and cooler Antarctic Surface Water (temperatures of $\sim-2^{\circ} \mathrm{C}$ and salinity of 34.2). Flow is mostly barotropic along the shelf break except for baroclinic bottom-intensified flows at areas of changing bathymetry (such as the Dalton rise).

On the Totten region continental shelf, the water masses include slightly cooler but salty CDW (MCDW formed through mixing with shelf waters); this is overlayed by cold and fresh Antarctic Surface Water; while along the coastline, a seasonally varying cold and salty HSSW (with temperatures of $\sim-2{ }^{\circ} \mathrm{C}$ or less and salinity of 34.7 or greater) flows westwards. On the shelf, model output shows the westward flow of HSSW is bottom-intensified and can entrain surface waters with it. The flow of the $\mathrm{ACoC}$ is generally surface-intensified and carries meltwater from the Dalton ice shelf and ice tongue westwards, however, these two flows can combine to form approximately-barotropic westward flow. A large clockwise recirculation feature forms in the Totten basin. This feature, which is surface intensified, carries heat clockwise from the shelf break towards both major ice shelves, and is composed of water with temperature between -0.2 to $0.4{ }^{\circ} \mathrm{C}$ and salinity of 34.5 to 34.6 .

\section{Discussion}

Model results show variability in melt rate over the course of each year. However, the interannual Totten melt rate, the dashed black line in Fig. 2c, shows variation from high to low melt rate and vice versa, with a $\sim 2-3$ year period. The $\sim 2-3$ year modulation of melt rate signal is noticeable as an increasing annual average melt between 1992 to 1994 (most visible in the 3-month Totten melt rate, shown as the red line in Fig. 2c), 1998 to 2002, 2004 to 2007 and decreasing annual average melt between 1994 to 1998 and between 2002 and 2004. This pattern of increasing and decreasing melt repeats over the 1992-2007 period. However, there is no overall trend (over the 1992-2007 period) in Totten ice shelf melt discernible above the $\sim 2-3$ year melt variation. Thus, we focus the analysis on understanding the processes governing simulated interannual variability in melt rates.

Satellite-derived estimates of ice shelf thinning indicate that for the period 2003-2008 thinning of the Totten ice shelf was the fourth highest in Antarctica (Pritchard et al., 2012). Over the period 2003-2007, the model area-averaged melt 

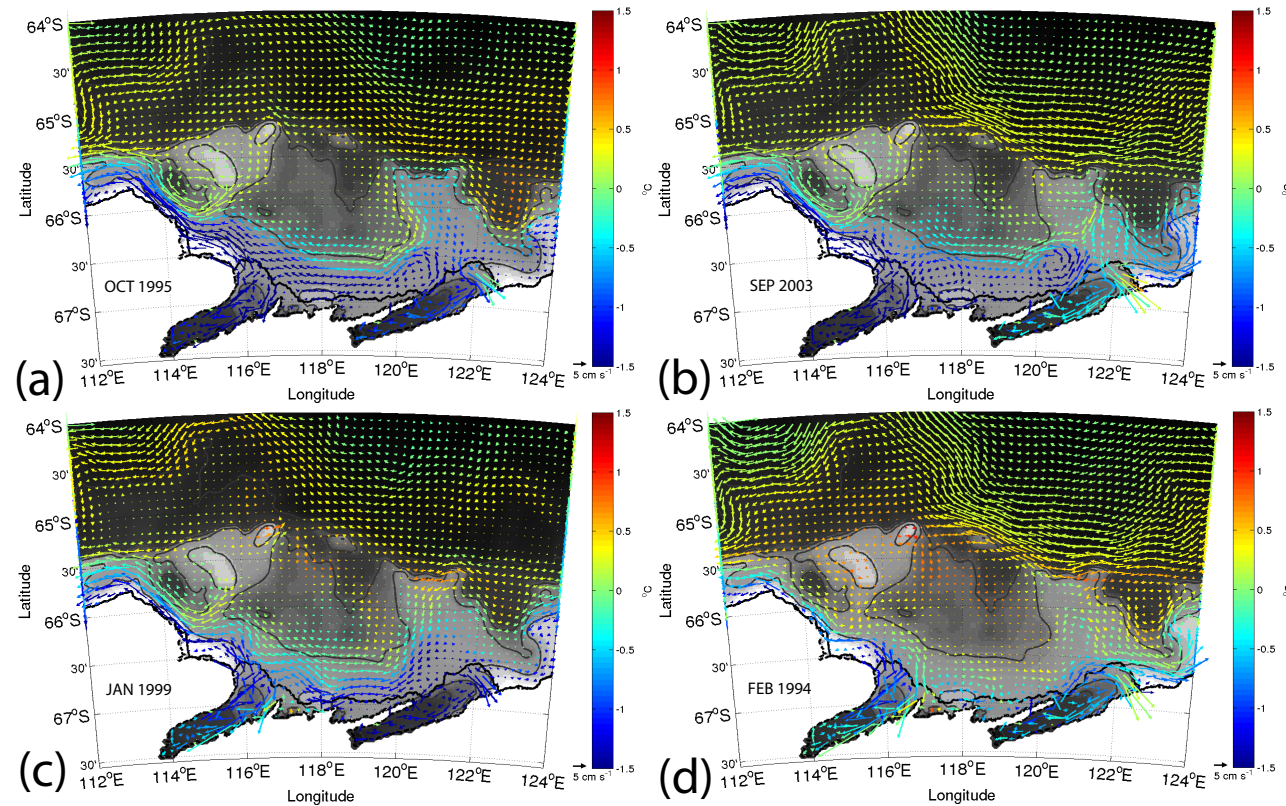

Fig. 5. Simulated column-averaged currents (excluding the surface layer), where the vectors are coloured for mean column temperature, and scaled according to the reference vector. (a) October 1995. Strong winds drive polynya activity and the ACoC, inhibiting heat flow to the Totten ice shelf. There is no flow over the Dalton rise. (b) September 2003. Strong polynya activity increases HSSW production, preventing warm water entry to the Totten ice shelf cavity and decreasing melt rates. Flow over the Dalton rise supplies heat for melting to the Dalton ice shelf. (c) January 1999. Polynya activity and ACoC are weak, allowing heat supply to cause melting of the Totten ice shelf. There is no flow over the Dalton rise, so Dalton ice shelf melt rates drop. (d) February 1994. Polynya activity and ACoC are very weak, allowing warm inflow to Totten ice shelf. Flow over the Dalton rise can increase melting of Dalton ice shelf.

rate increased to its highest value, in agreement with an ice shelf that is rapidly thinning.

Oceanic heat is supplied to both ice shelves across the continental slope. However, variability in heat supply at the ice shelves is also dependent on the nearby Dalton ice tongue polynya. HSSW produced by the polynya can flow westwards, reducing supply of heat into the Totten ice shelf cavity. We proceed by examining model currents and atmosphere-ocean exchange together with variability in ice shelf melt rate.

\subsection{Atmosphere-ocean exchange}

Strong katabatic winds that drive polynya activity, are also partly responsible for driving the ACoC. Generally, as polynya activity increases from March to April, large quantities of HSSW are formed in the model. When the polynya is strongly active, the $\mathrm{ACoC}$ is also strong and the resulting westward flow directs most of the HSSW towards the Totten ice shelf. As polynya activity decreases in August, production of HSSW decreases, allowing warm slope front current (which flows across the continental shelf break and into the Totten basin), access to the ice shelf cavity to drive high melt of the Totten ice shelf.

Times when HSSW production and ACoC are strong lead to cold, dense HSSW entering the ice shelf cavity and decreased melting. However, the timing of the minimum of Totten ice shelf melt (generally in December) lags the peak in polynya activity and HSSW production in June (compare Fig. $2 \mathrm{c}$ and a). Increasing polynya activity causes the rate of change of melt rate to become negative and so the melt rate passes through a local maximum. The melt rate continues to decrease until polynya activity decreases, at which point the rate of change of melt rate becomes positive. The melt rate then passes through a local minimum and increases. The lag between polynya maximum and Totten melt minimum is created because the bulk volume of water below the ice shelf requires time to cool as HSSW is added and time to heat up as warm water is added. The Dalton ice shelf exhibits a similar temporal pattern of melt rate as the Totten ice shelf, suggesting that polynya activity is an influential factor on Dalton melt rate as well.

The heat flux anomaly for the Dalton ice tongue polynya region is shown in Fig. 2b. Here, a positive signal indicates stronger than average heat loss to the atmosphere and stronger HSSW production.

From 1993 to 1995 , the heat flux anomaly was negative during the middle of the year, suggesting weaker peak polynya strength. Consequently, both ice shelves display strong melting. From 1996 to 1998, the heat flux anomaly was strongly positive, leading to strong HSSW production and the Totten progressively decreasing in melt rate 
during this period. From mid-1999 to mid-2002, the heat flux anomaly was negative and consequently, HSSW production dropped and oceanic heat supply increased to both ice shelves. Annual average melt was thus higher for this period than for the 1996-1998 period when the heat flux anomaly was strongly positive. From late 2002 to 2004, the heat flux anomaly was weakly positive, coinciding with weakened melt rates. For mid-2004 and from 2005 to 2007, the heat flux anomaly was again strongly negative, which led to reduced production of HSSW and increased melt as heat supply increased. The years with a strong seasonal variation in melt rate (see 1992 through to 1996) are years when atmosphereocean exchange (in the form of heat loss to the atmosphere) was the dominant mechanism modulating seasonal variation in the melt rate. Other years, such as 1998 and 2003, displayed a more complex melt rate evolution that was likely a combination of atmospheric forcing and melting caused by a time-dependent warm water source.

The seasonal changes in atmosphere-ocean fluxes explains the seasonal evolution of melt of both ice shelves, while the heat flux anomaly explains the interannual trend in melt rate of both ice shelves. However, there were several periods when the melt rate of the Totten and Dalton ice shelves fluctuated quite differently from each other, indicating melting not driven solely by polynya activity.

\subsection{Shelf exchange processes and heat supply for melting}

The primary source of heat for melting is supplied across the continental shelf. Bathymetry is important for controlling intrusion of warm water by guiding the slope current. Model results show that regional topographic features (the Dalton rise and Totten basin) act to guide water onto the continental shelf. These features are regions of intermittent warm inflow. The mechanism by which the flow of the ASC can be diverted by bathymetry is probably different for each topographic feature.

Geostrophic flows tend to conserve potential vorticity $f / H$, where $f$ is the Coriolis parameter (which varies with latitude) and $H$ represents the water depth, leading to the tendency of geostrophic flows primarily following isobaths. If a change in bathymetry is encountered, resulting flow will tend to divert to a different latitude to counter the change in depth. In the model results, we see this by the poleward current generated as the ASC interacts with the edge of the Totten basin. The narrow current formation is supported by idealised modelling studies, which suggest a significant onshore flow is generated by interaction with flow along the shelf break and a trough (St-Laurent et al., 2013).

Melting of the Dalton ice shelf is strengthened by occasional flow of warm water into the basin of Paulding Bay, east of the Dalton rise. Model currents suggest counter-clockwise circulation forming in Paulding Bay when the ASC impacts with the north-eastern tip of the Dalton rise. The resulting circulation is onto the Dalton rise and into the ice shelf cavity (see Fig. 5b).

The difference between the simulated Totten and Dalton melt rates is shown in Fig. 2d. A positive value indicates the Totten melting is lower than Dalton, while a negative value indicates Dalton melting is weaker than Totten. The signal is smoothed by a 6 -month moving average and \pm 1 standard deviation is shaded. A difference greater in magnitude than 1 standard deviation indicates periods when the melt rates of the Totten and Dalton ice shelves are significantly uncorrelated. Since polynya activity drives the melt rate signal on a seasonal timescale, significantly different melt rates indicate times when the melt rate of at least one of the ice shelves is not purely driven by polynya activity.

Late 1996, late 2000, late 2003 and late 2007 were times when there was a strong supply of heat to the Dalton ice shelf, but not to the Totten ice shelf (see Fig. 2d). During these times, oceanic currents supplied heat over the Dalton rise only to the Dalton ice shelf, but polynya activity and formation of cold, dense HSSW was strong enough to limit Totten melting (see Fig. 5b). Circulation also shows cold Dalton melt water leaving the cavity and flowing westwards to the Totten ice shelf cavity.

Late 1998, early 1999 and late 2007 were times when the Totten ice shelf experienced strong melting but the Dalton ice shelf did not. Polynya activity at these times was weaker than average, which led to lower rates of HSSW production. Model circulation at these times shows weak flow of HSSW to the Totten ice shelf (see Fig. 5c). Warm water that intrudes into the Totten basin can consequently enter the ice shelf cavity and drive increased melting. Weaker westward $\mathrm{ACoC}$ flow results in HSSW flowing into the nearby Dalton ice shelf cavity, decreasing Dalton melting.

\subsection{Melt rate forcing by a combination of polynya activity and circulation}

The melt rates displayed by both the Totten and Dalton ice shelves are a complex combination of a seasonal signal with occasional periods of very high and very low melt. Comparing melt rate and polynya activity, as shown in Fig. 2c and $b$, we see that in general, periods of lower melt are correlated with periods of stronger polynya activity. However, there were several short periods when ocean circulation features caused the melt rate of the Dalton and Totten ice shelves to be out of phase. This suggests that a combination of atmosphere-ocean exchange and shelf break flow mechanisms is required to fully explain the melt rate of the Dalton and Totten ice shelves.

We propose a set of four main states of circulation and polynya activity, that drive melt of the Dalton and Totten ice shelves. These four states describe the configuration of onshelf flow and polynya activity, and explain the seasonal and interannual variation of the melt rate of the Totten and Dalton ice shelves. These states are described as follows: 


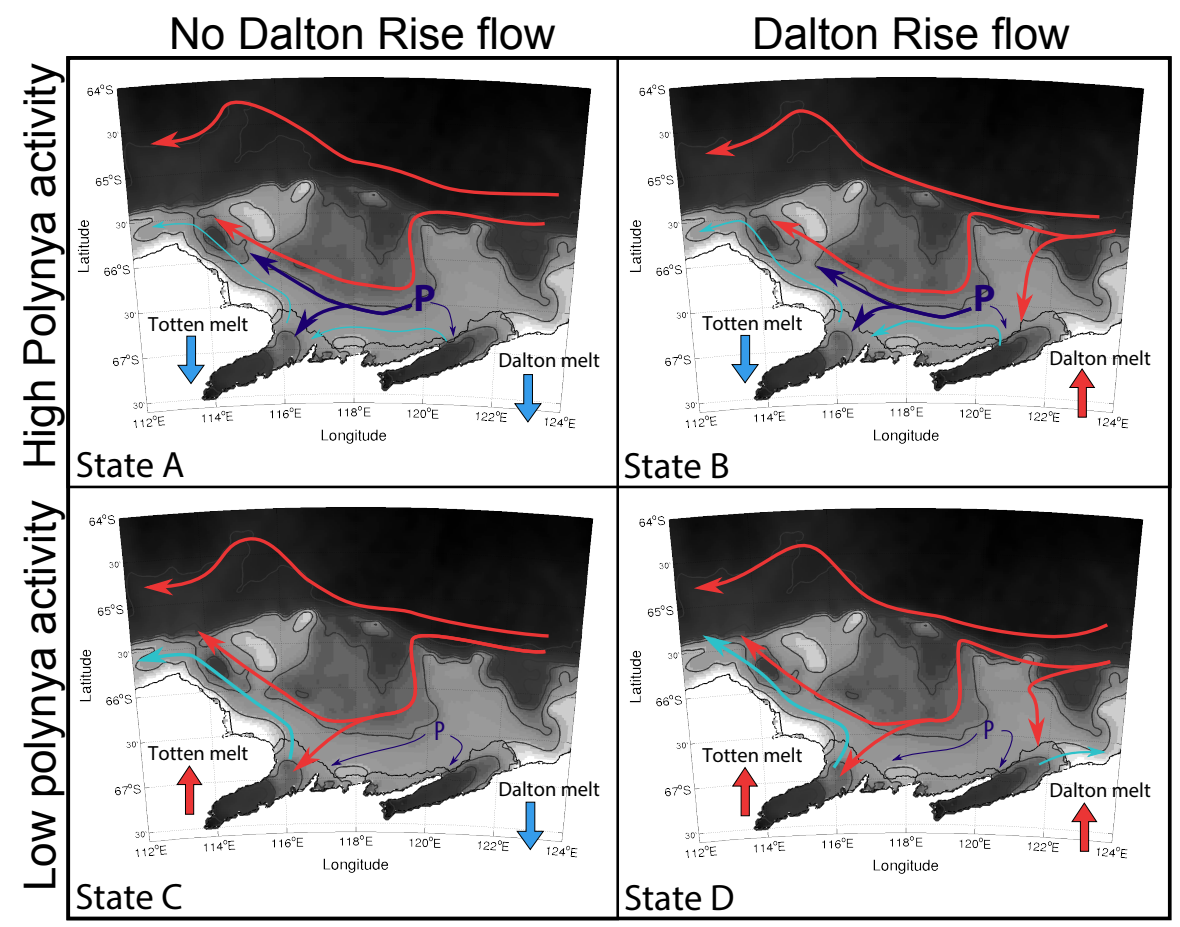

Fig. 6. ASC (light red line), HSSW (dark blue line) and ice shelf meltwater (light blue line) are shown for; States (A): here, polynya activity is strong (as shown by a bold "P"), but the ASC only enters the Totten basin. Consequently, both ice shelves show lowered melt rates. (B): polynya activity is strong, however the ASC comes onshore on both sides of the Dalton rise, leading to increased Dalton ice shelf melt rates. HSSW produced by the polynya and Dalton ice shelf melt water combine to lower Totten melt rates. (C): polynya activity is weak (as shown by a thinner "P") and warm water only flows into the Totten basin. Consequently, the Totten ice shelf displays strong melting, while the Dalton ice shelf displays weak melting. (D): polynya activity is weak and warm water onflow over the Dalton rise and into the Totten basin lead to high melt rates for both ice shelves.

- State A: The meridional position of the ASC means that it interacts only with the western edge of the Dalton rise. The resulting jet flows southward into the Totten basin, following the isobaths clockwise until it rejoins the ASC north of Law Dome. The polynya and ACoC are strongly active, causing HSSW to flow into the Dalton ice shelf cavity and westwards to the Totten ice shelf cavity inhibiting melting of both ice shelves. This state is illustrated in Fig. 6a and shown in model currents in Fig. 5a and melt rate anomaly distribution is shown in Fig. 4a.

- State B: Polynya activity is strong, but now the ASC interacts with the bathymetry offshore of the Dalton rise, which gives rise to a warm current over the Dalton rise, directly to the mouth of the Dalton ice shelf. The increased melting leads to a strong meltwater outflow westwards towards the Totten ice shelf, inhibiting melting of the Totten. The Totten ice shelf shows very low melt rates, while the Dalton ice shelf displays strong melting, as illustrated in Fig. $6 \mathrm{~b}$ and shown in model currents in Fig. $5 \mathrm{~b}$ and melt rate anomaly distribution in Fig. 4b.
- State C: Weak polynya activity and ACoC strength leads to reduced HSSW flow to both the Totten and Dalton ice shelves. The ASC only interacts with the western edge of the Dalton rise, generating a warm current into the Totten basin, which drives strong Totten ice shelf melting. Since the Dalton ice shelf has very little warm inflow, the lowered HSSW production is enough to inhibit melting. This state is shown in Fig. 6c and shown in model currents in Fig. 5c and in melt rate anomaly distribution in Fig. 4c.

- State D: Polynya activity and ACoC strength is much weaker than in States A and B. As a result, HSSW production is lowered and transport of dense, cold water to both the Dalton and Totten ice shelves decreases. The ASC interacts with the Dalton rise, leading to a warm currents flooding the Totten and the Dalton ice shelves. Both ice shelves thus display high melting, but the weak ACoC means that Dalton melt water (which now flows eastwards) does not limit Totten melting as in State B. This state is illustrated in Fig. 6d and shown in model currents in Fig. 5d and in melt rate anomaly distribution in Fig. 4d. 


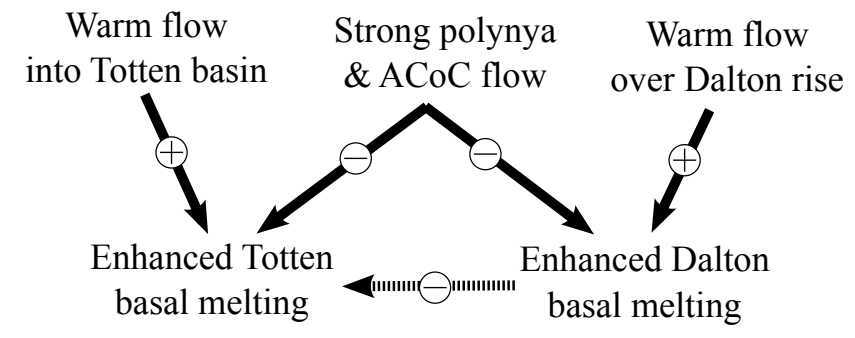

Fig. 7. The interaction between the Totten and Dalton ice shelves, the Dalton ice tongue polynya and on shelf flow is summarised. A negative interaction is shown by $\ominus$, while a positive interaction is shown by $\oplus$. Strong polynya and ACoC flow has a negative impact on warm water supply to both ice shelves, while warm water flow into the Totten basin and over the Dalton rise has a positive impact on basal melting of the Totten and Dalton ice shelves, respectively. Increased basal melting of the Dalton ice shelf can have a strong negative affect on the Totten ice shelf. The dependence of this last interaction on strong $\mathrm{ACoC}$ flow is shown by the dashed line.

The interactions described by these four states, represented in Fig. 7, summarise the melt rate controls of the Dalton and Totten ice shelves. This interaction chart shows the strong negative impact of polynya activity and $\mathrm{ACoC}$ strength on heat supply to both ice shelves. Warm water intrusions that flow over the shelf break can interact with the shelf bathymetry and supply heat to either ice shelf, which will result in enhanced basal melting. If heat is supplied to the Dalton ice shelf, increased melting may lead to a decrease in heat supply for the Totten ice shelf (via outflow of cold Dalton melt water).

These interactions provide a hypothesis describing likely causes of melting of these under-researched ice shelves. A similar mechanism has been proposed linking basal melt of the Mertz Glacier Tongue and a nearby polynya (Cougnon et al., 2013).

This is also the first evidence of the interaction between two ice shelves, where the melt rate of one ice shelf affects the melt rate of the other. This indicates that the melt rate and glaciology of the Totten ice shelf cannot be studied in isolation from the Dalton ice shelf.

\section{Conclusions}

Remote sensing observations show thinning of the Totten Glacier and suggest strong basal melting of the Totten ice shelf, driven by changing ocean conditions as the most likely explanation. Previous studies have indicated that enhanced exchange of heat across the shelf break is a major cause of increased basal melting (see for example Jacobs et al., 2013). This study shows that, along with exchange of heat across the shelf break, atmosphere-ocean interaction processes on the continental shelf can modify oceanic heat supply to ice shelves, and modulate basal melting.
Dense water formation in the Dalton ice tongue polynya strongly modulates the seasonality of melting for both ice shelves. Melting of the Totten ice shelf is increased when the interannual strength of the Dalton polynya is below average, and vice versa. The Dalton ice shelf melt rate is primarily controlled by intrusions of warm water across the Dalton rise and into the ice shelf cavity. Simulated area-averaged melt rates for the Totten ice shelf agree well with recent glaciological estimates, and suggest the Dalton ice shelf, like the Totten, as being a region of high basal melting.

Furthermore, this study suggests important evidence for the interaction between two ice shelves, where the melting of one directly influences the melting of the other. Lastly, strong interannual variability in heat supply to the ice shelves and subsequent melt rates suggest that observations will need to be long to correctly determine attributable mechanisms.

This is the first such modelling study of this region, and provides valuable information for directing future observations.

Acknowledgements. This work was supported by the Australian Government's Cooperative Research Centre Programme through the Antarctic Climate \& Ecosystems Cooperative Research Centre. David Gwyther is supported by the CSIRO and UTAS through the Quantitative Marine Science PhD program.

David Gwyther wishes to acknowledge and thank the helpful comments and suggestions given by Ben Caspani. Early guidance with analysis was provided by Guy Williams. We also thank the two reviewers for their thorough review of the manuscript. Computing resources were provided by both the Tasmanian Partnership for Advanced Computing and the National Computational Infrastructure under grant $\mathrm{m} 68$.

Edited by: M. Hoppema

\section{References}

Bindoff, N. L., Rosenberg, M. A., and Warner, M. J.: On the circulation and water masses over the Antarctic continental slope and rise between 80 and $150^{\circ}$ E, Deep-Sea Res.-Pt. II, 47, 22992326, doi:10.1016/S0967-0645(00)00038-2, 2000.

Böning, C. W., Dispert, A., Visbeck, M., Rintoul, S. R., and Schwarzkopf, F. U.: The response of the Antarctic Circumpolar Current to recent climate change, Nat. Geosci., 1, 864-869, doi:10.1038/ngeo362, 2008.

British Oceanographic Data Centre: Centenary Edition of the GEBCO Digital Atlas, [CD-ROM]: Published on behalf of the Intergovernmental Oceanographic Commission and the International Hydrographic Organization, Liverpool, UK, 2003.

Budgell, W.: Numerical simulation of ice-ocean variability in the Barents Sea region, Ocean Dynam., 55, 370-387, doi:10.1007/s10236-005-0008-3, 2005.

Church, J. A., White, N. J., Konikow, L. F., Domingues, C. M., Cogley, J. G., Rignot, E., Gregory, J. M., van den Broeke, M. R., Monaghan, A. J., and Velicogna, I.: Revisiting the Earth's sea- 
level and energy budgets from 1961 to 2008 , Geophys. Res. Lett., 38, 1-8, doi:10.1029/2011GL048794, 2011.

Cougnon, E. A., Galton-Fenzi, B. K., Meijers, A. J. S., and Legrésy, B.: Modelling inter-annual dense shelf water export in the region of the Mertz Glacier Tongue (1992-2007), J. Geophys. Res.Oceans, 118, 5858-5872, doi:10.1002/2013JC008790, 2013.

De Angelis, H. and Skvarca, P.: Glacier surge after ice shelf collapse, Science, 299, 1560-1562, doi:10.1126/science.1077987, 2003.

Depoorter, M. A., Bamber, J. L., Griggs, J. A., Lenaerts, J. T. M., Ligtenberg, S. R. M., van den Broeke, M. R., and Moholdt, G.: Calving fluxes and basal melt rates of Antarctic ice shelves, Nature, 502, 89-92, doi:10.1038/nature12567, 2013.

Dinniman, M. S. and Klinck, J. M.: A model study of circulation and cross-shelf exchange on the west Antarctic Peninsula continental shelf, Deep-Sea Res.-Pt. II, 51, 2003-2022, doi:10.1016/j.dsr2.2004.07.030, 2004.

Dinniman, M. S., Klinck, J. M., and Smith, W. O.: Influence of sea ice cover and icebergs on circulation and water mass formation in a numerical circulation model of the Ross Sea, Antarctica, J. Geophys. Res., 112, C11013, doi:10.1029/2006JC004036, 2007.

Dupont, T. K. and Alley, R. B.: Assessment of the importance of ice-shelf buttressing to ice-sheet flow, Geophys. Res. Lett., 32, 1-4, doi:10.1029/2004GL022024, 2005.

Fraser, A. D., Massom, R. a., Michael, K. J., Galton-Fenzi, B. K., and Lieser, J. L.: East Antarctic Landfast Sea Ice Distribution and Variability, 2000-08, J. Climate, 25, 1137-1156, doi:10.1175/JCLI-D-10-05032.1, 2012.

Fretwell, P., Pritchard, H. D., Vaughan, D. G., Bamber, J. L., Barrand, N. E., Bell, R., Bianchi, C., Bingham, R. G., Blankenship, D. D., Casassa, G., Catania, G., Callens, D., Conway, H., Cook, A. J., Corr, H. F. J., Damaske, D., Damm, V., Ferraccioli, F., Forsberg, R., Fujita, S., Gim, Y., Gogineni, P., Griggs, J. A., Hindmarsh, R. C. A., Holmlund, P., Holt, J. W., Jacobel, R. W., Jenkins, A., Jokat, W., Jordan, T., King, E. C., Kohler, J., Krabill, W., Riger-Kusk, M., Langley, K. A., Leitchenkov, G., Leuschen, C., Luyendyk, B. P., Matsuoka, K., Mouginot, J., Nitsche, F. O., Nogi, Y., Nost, O. A., Popov, S. V., Rignot, E., Rippin, D. M., Rivera, A., Roberts, J., Ross, N., Siegert, M. J., Smith, A. M., Steinhage, D., Studinger, M., Sun, B., Tinto, B. K., Welch, B. C., Wilson, D., Young, D. A., Xiangbin, C., and Zirizzotti, A.: Bedmap2: improved ice bed, surface and thickness datasets for Antarctica, The Cryosphere, 7, 375-393, doi:10.5194/tc-7-3752013, 2013.

Galton-Fenzi, B., Maraldi, C., Coleman, R., and Hunter, J.: The cavity under the Amery Ice Shelf, East Antarctica, J. Glaciol., 54, 881-887, doi:10.3189/002214308787779898, 2008.

Galton-Fenzi, B. K., Hunter, J. R., Coleman, R., Marsland, S. J., and Warner, R. C.: Modeling the basal melting and marine ice accretion of the Amery Ice Shelf, J. Geophys. Res., 117, C09031, doi:10.1029/2012JC008214, 2012.

Gille, S. T.: Decadal-Scale Temperature Trends in the Southern Hemisphere Ocean, J. Climate, 21, 4749-4765, doi:10.1175/2008JCLI2131.1, 2008.

Gregory, J. M., White, N. J., Church, J. A., Bierkens, M. F. P., Box, J. E., Van den Broeke, M. R., Cogley, J. G., Fettweis, X., Hanna, E., Huybrechts, P., Konikow, L. F., Leclercq, P. W., Marzeion, B., Oerlemans, J., Tamisiea, M. E., Wada, Y., Wake, L. M., and Van de Wal, R. S. W.: Twentieth-century global-mean sea-level rise: Is the Whole Greater than the sum of the parts?, J. Climate, 26, 4476-4499, doi:10.1175/JCLI-D-12-00319.1, 2013.

Hattermann, T., Smedsrud, L. H., Nøst, O. A., Lilly, J. M., and Galton-fenzi, B. K.: Eddy-resolving model reveals two states of basal melting below Fimbul Ice Shelf, Antarctica, in review, 2014.

Hellmer, H. H., Kauker, F., Timmermann, R., Determann, J., and Rae, J.: Twenty-first-century warming of a large Antarctic iceshelf cavity by a redirected coastal current, Nature, 485, 225228, doi:10.1038/nature11064, 2012.

Holland, D. M. and Jenkins, A.: Modeling Thermodynamic Ice-Ocean Interactions at the Base of an Ice Shelf, J. Phys. Oceanogr., 29, 1787-1800, doi:10.1175/15200485(1999)029<1787:MTIOIA>2.0.CO;2, 1999.

Holland, P. R., Jenkins, A., and Holland, D. M.: The Response of Ice Shelf Basal Melting to Variations in Ocean Temperature, J. Climate, 21, 2558-2572, doi:10.1175/2007JCLI1909.1, 2008.

Holland, P. R., Jenkins, A., and Holland, D. M.: Ice and ocean processes in the Bellingshausen Sea, Antarctica, J. Geophys. Res., 115, 1-16, doi:10.1029/2008JC005219, 2010.

Jacobs, S. S.: On the nature and significance of the Antarctic Slope Front, Mar. Chem., 35, 9-24, doi:10.1016/S03044203(09)90005-6, 1991.

Jacobs, S. S.: Bottom water production and its links with the thermohaline circulation, Antarct. Sci., 16, 427-437, doi:10.1017/S095410200400224X, 2004.

Jacobs, S. S., Hellmer, H. H., and Jenkins, A.: Antarctic ice sheet melting in the Southeast Pacific, Geophys. Res. Lett., 23, 957960, 1996.

Jacobs, S. S., Jenkins, A., Giulivi, C. F., and Dutrieux, P.: Stronger ocean circulation and increased melting under Pine Island Glacier ice shelf, Nat. Geosci., 4, 519-523, doi:10.1038/ngeo1188, 2011.

Jacobs, S. S., Giulivi, C., Dutrieux, P., Rignot, E., Nitsche, F., and Mouginot, J.: Getz Ice Shelf melting response to changes in ocean forcing, J. Geophys. Res.-Oceans, 118, 4152-4168, doi:10.1002/jgrc.20298, 2013.

Jamieson, S. S. R., Vieli, A., Livingstone, S. J., Cofaigh, C. Ó., Stokes, C., Hillenbrand, C.-D., and Dowdeswell, J. A.: Icestream stability on a reverse bed slope, Nat. Geosci., 5, 799-802, doi:10.1038/ngeo1600, 2012.

Jenkins, A., Dutrieux, P., Jacobs, S. S., McPhail, S. D., Perrett, J. R., Webb, A. T., and White, D.: Observations beneath Pine Island Glacier in West Antarctica and implications for its retreat, Nat. Geosci., 3, 468-472, doi:10.1038/ngeo890, 2010.

Kämpf, J.: Cascading-driven upwelling in submarine canyons at high latitudes, J. Geophys. Res., 110, C02007, doi:10.1029/2004JC002554, 2005.

Kämpf, J.: On the magnitude of upwelling fluxes in shelf-break canyons, Cont. Shelf Res., 27, 2211-2223, doi:10.1016/j.csr.2007.05.010, 2007.

Klinck, J. M. and Dinniman, M. S.: Exchange across the shelf break at high southern latitudes, Ocean Sci., 6, 513-524, doi:10.5194/os-6-513-2010, 2010.

Kusahara, K., Hasumi, H., and Tamura, T.: Modeling sea ice production and dense shelf water formation in coastal polynyas around East Antarctica, J. Geophys. Res., 115, C10006, doi:10.1029/2010JC006133, 2010. 
Large, W. G. and Yeager, S. G.: The global climatology of an interannually varying air-sea flux data set, Clim. Dynam., 33, 341364, doi:10.1007/s00382-008-0441-3, 2009.

Lewis, E. L. and Perkin, R. G.: Ice Pumps and Their Rates, J. Geophys. Res., 91, 11756-11762, doi:10.1029/JC091iC10p11756, 1986.

Marks, K. M. and Smith, W. H. F.: An Evaluation of Publicly Available Global Bathymetry Grids, Mar. Geophys. Res., 27, 19-34, doi:10.1007/s11001-005-2095-4, 2006.

Martinson, D. G. and McKee, D. C.: Transport of warm Upper Circumpolar Deep Water onto the western Antarctic Peninsula continental shelf, Ocean Sci., 8, 433-442, doi:10.5194/os-8-4332012, 2012.

Massom, R. A., Harris, P. T., Michael, K. J., and Potter, M. J.: The distribution and formative processes of latent-heat polynyas in East Antarctica, Ann. Glaciol., 27, 420-426, 1998.

Massom, R. A., Hill, K. L., Lytle, V. I., Worby, A. P., Paget, M. J., and Allison, I.: Effects of regional fast-ice and iceberg distributions on the behaviour of the Mertz Glacier polynya, East Antarctica, Ann. Glaciol., 33, 391-398, 2001.

Mathiot, P., Goosse, H., Fichefet, T., Barnier, B., and Gallée, H.: Modelling the seasonal variability of the Antarctic Slope Current, Ocean Sci., 7, 455-470, doi:10.5194/os-7-455-2011, 2011.

Menemenlis, D., Campin, J.-M., Heimbach, P., Hill, C., Lee, T., Nguyen, A., Schodlok, M., and Zhang, H.: ECCO2 : High Resolution Global Ocean and Sea Ice Data Synthesis, Mercator Ocean Quarterly Newsletter, 31, 13-21, 2008.

Moffat, C., Owens, B., and Beardsley, R. C.: On the characteristics of Circumpolar Deep Water intrusions to the west Antarctic Peninsula Continental Shelf, J. Geophys. Res., 114, C05017, doi:10.1029/2008JC004955, 2009.

Nikurashin, M. and Ferrari, R.: Radiation and Dissipation of Internal Waves Generated by Geostrophic Motions Impinging on Small-Scale Topography: Application to the Southern Ocean, J. Phys. Oceanogr., 40, 2025-2042, doi:10.1175/2010JPO4315.1, 2010.

Orsi, A. H., Whitworth III, T., and Nowlin Jr., W. D.: On the meridional extent and fronts of the Antarctic Circumpolar Current, Deep-Sea Res.-Pt. I, 42, 641-673, 1995.

Pritchard, H. D., Arthern, R. J., Vaughan, D. G., and Edwards, L. A.: Extensive dynamic thinning on the margins of the Greenland and Antarctic ice sheets, Nature, 461, 971-975, doi:10.1038/nature08471, 2009.

Pritchard, H. D., Ligtenberg, S. R. M., Fricker, H. A., Vaughan, D. G., van den Broeke, M. R., and Padman, L.: Antarctic icesheet loss driven by basal melting of ice shelves, Nature, 484, 502-505, doi:10.1038/nature10968, 2012.

Rignot, E. J.: Mass balance of East Antarctic glaciers and ice shelves from satellite data, Ann. Glaciol., 34, 217-227, doi:10.3189/172756402781817419, 2002.

Rignot, E.: Changes in ice dynamics and mass balance of the Antarctic ice sheet, Philos. T. Roy. Soc. A, 364, 1637-1655, doi:10.1098/rsta.2006.1793, 2006.

Rignot, E. J. and Jacobs, S. S.: Rapid bottom melting widespread near Antarctic Ice Sheet grounding lines, Science, 296, 20202023, doi:10.1126/science.1070942, 2002.

Rignot, E. J., Bamber, J. L., van den Broeke, M. R., Davis, C., Li, Y., van de Berg, W. J., and van Meijgaard, E.: Recent Antarctic ice mass loss from radar interferometry and regional climate modelling, Nat. Geosci., 1, 106-110, doi:10.1038/ngeo102, 2008.

Rignot, E., Jacobs, S., Mouginot, J., and Scheuchl, B.: Ice Shelf Melting Around Antarctica, Science, 341, 266-270, doi:10.1126/science.1235798, 2013.

Rintoul, S. R., Hughes, C. W., and Olbers, D.: Chapter 4.6 The antarctic circumpolar current system, in: Ocean Circulation and Climate Observing and Modelling the Global Ocean, edited by: Gerold Siedler, J. C. and Gould, J., Vol. 77 of International Geophysics, 271-302, Academic Press, doi:10.1016/S00746142(01)80124-8, 2001.

Roberts, J. L., Warner, R. C., Young, D., Wright, A., van Ommen, T. D., Blankenship, D. D., Siegert, M., Young, N. W., Tabacco, I. E., Forieri, A., Passerini, A., Zirizzotti, A., and Frezzotti, M.: Refined broad-scale sub-glacial morphology of Aurora Subglacial Basin, East Antarctica derived by an ice-dynamics-based interpolation scheme, The Cryosphere, 5, 551-560, doi:10.5194/tc-5551-2011, 2011.

Scambos, T. A., Bohlander, J. A., Shuman, C. A., and Skvarca, P.: Glacier acceleration and thinning after ice shelf collapse in the Larsen B embayment, Antarctica, Geophys. Res. Lett., 31, L18402, doi:10.1029/2004GL020670, 2004.

Shchepetkin, A. F. and McWilliams, J. C.: The regional oceanic modeling system (ROMS): a split-explicit, free-surface, topography-following-coordinate oceanic model, Ocean Model., 9, 347-404, doi:10.1016/j.ocemod.2004.08.002, 2005.

Smith, W. and Sandwell, D.: Global sea floor topography from satellite altimetry and ship depth soundings, Science, 2, 209-215, 1997.

St-Laurent, P., Klinck, J. M., and Dinniman, M. S.: On the Role of Coastal Troughs in the Circulation of Warm Circumpolar Deep Water on Antarctic Shelves, J. Phys. Oceanogr., 43, 51-64, doi:10.1175/JPO-D-11-0237.1, 2013.

Tamura, T., Ohshima, K. I., and Nihashi, S.: Mapping of sea ice production for Antarctic coastal polynyas, Geophys. Res. Lett., 35, L07606, doi:10.1029/2007GL032903, 2008.

Thoma, M., Jenkins, A., Holland, D., and Jacobs, S.: Modelling Circumpolar Deep Water intrusions on the Amundsen Sea continental shelf, Antarctica, Geophys. Res. Lett., 35, L18602, doi:10.1029/2008GL034939, 2008.

Timmermann, R., Le Brocq, A., Deen, T., Domack, E., Dutrieux, P., Galton-Fenzi, B., Hellmer, H., Humbert, A., Jansen, D., Jenkins, A., Lambrecht, A., Makinson, K., Niederjasper, F., Nitsche, F., Nøst, O. A., Smedsrud, L. H., and Smith, W. H. F.: A consistent data set of Antarctic ice sheet topography, cavity geometry, and global bathymetry, Earth Syst. Sci. Data, 2, 261-273, doi:10.5194/essd-2-261-2010, 2010.

Weertman, J.: Stability of the junction of an ice sheet and an ice shelf, J. Glaciol., 13, 3-11, 1974.

Williams, G. D., Meijers, A. J. S., Poole, A., Mathiot, P., Tamura, T., and Klocker, A.: Late winter oceanography off the Sabrina and BANZARE coast (117-128 E), East Antarctica, Deep Sea Res.Pt. II, 58, 1194-1210, doi:10.1016/j.dsr2.2010.10.035, 2011.

Young, D. A., Wright, A. P., Roberts, J. L., Warner, R. C., Young, N. W., Greenbaum, J. S., Schroeder, D. M., Holt, J. W., Sugden, D. E., Blankenship, D. D., van Ommen, T. D., and Siegert, M. J.: A dynamic early East Antarctic Ice Sheet suggested by ice-covered fjord landscapes, Nature, 474, 72-75, doi:10.1038/nature10114, 2011. 